\title{
Changing times, changing stories: generational differences in climate change perspectives from four remote indigenous communities in Subarctic Alaska
}

\author{
$\underline{\text { Nicole M. Herman-Mercer }}^{1}, \underline{\text { Elli Matkin }}^{2}, \underline{\text { Melinda J. Laituri }}^{3,4}$, Ryan C. Toohey $^{5,6}$, Maggie Massey $^{7}, \underline{\text { Kelly Elder }}^{8}, \underline{\text { Paul F. Schuster }}^{1}$
} and Edda A. Mutter $^{7}$

\begin{abstract}
Indigenous Arctic and Subarctic communities currently are facing a myriad of social and environmental changes. In response to these changes, studies concerning indigenous knowledge (IK) and climate change vulnerability, resiliency, and adaptation have increased dramatically in recent years. Risks to lives and livelihoods are often the focus of adaptation research; however, the cultural dimensions of climate change are equally important because cultural dimensions inform perceptions of risk. Furthermore, many Arctic and Subarctic IK climate change studies document observations of change and knowledge of the elders and older generations in a community, but few include the perspectives of the younger population. These observations by elders and older generations form a historical baseline record of weather and climate observations in these regions. However, many indigenous Arctic and Subarctic communities are composed of primarily younger residents. We focused on the differences in the cultural dimensions of climate change found between young adults and elders. We outlined the findings from interviews conducted in four indigenous communities in Subarctic Alaska. The findings revealed that (1) intergenerational observations of change were common among interview participants in all four communities, (2) older generations observed more overall change than younger generations interviewed by us, and (3) how change was perceived varied between generations. We defined "observations" as the specific examples of environmental and weather change that were described, whereas "perceptions" referred to the manner in which these observations of change were understood and contextualized by the interview participants. Understanding the differences in generational observations and perceptions of change are key issues in the development of climate change adaptation strategies.
\end{abstract}

Key Words: Alaska; climate change; indigenous knowledge; observation; perception; Yukon River Basin

\section{INTRODUCTION}

Indigenous Arctic and Subarctic communities are currently facing a myriad of both social and environmental changes (ACIA 2005, Hinzman et al. 2005, Moerlein and Carothers 2012, Larsen et al. 2014). These changes have the potential to affect traditional knowledge systems and livelihoods and to stress the adaptive capacities of indigenous communities. In response to the accelerating rate of environmental change in the Arctic and Subarctic, studies focused on indigenous knowledge (IK) and climate change vulnerability, resiliency, and adaptation have increased dramatically in recent years (Berkes 1999, Cruikshank 2001, Nuttall 2001, Reidlinger and Berkes 2001, Fox 2002, Krupnik and Jolly 2002, Herman-Mercer et al. 2011, McNeeley and Shulski 2011, Moerlein and Carothers 2012, Wilson 2014). The risks to lives and livelihoods attributable to climate change are often the focus of adaptation research (Adger et al. 2013). However, understanding the cultural dimensions of climate change is equally important because culture shapes the way that a community interacts with and the relationship a community has with its environment, which influences the ways social groups interpret and respond to risk (Beck 2009, Adger et al. 2013). Individual perceptions of the environment and climate change are informed by the larger culture of the community. However, culture is dynamic, and changing conditions within a society can spur changing understandings of a culture's relationship with its environment. Therefore, environmental and cultural changes may affect the sustainability, transmission, and applicability of certain components of IK.
In addition to emphasizing risks to lives and livelihood, many studies also focus on documenting observations of change and knowledge of the elders and older generations in a community (Herman-Mercer et al. 2011, Carothers et al. 2014, Wilson 2014). This documentation is critical because observations made by elders and older generations form a historical baseline record of weather and climate observations in Arctic and Subarctic regions where historical scientific data often are lacking (ACIA 2005, Bieniek et al. 2012). However, as Krupnik and Vakhtin (1997:237) point out, "Modern Native communities are not built exclusively of elders, experienced hunters and resource users, but consist of a great variety of Native (as well as non-Native) residents of various ages, social and educational background, and occupations." In our study area, Kusilvak County, Alaska, the median age of the population is 21.9 years (U.S. Census Bureau $2010 b$ ), making it the youngest county in the United States (Thomas 2012). These younger residents, barring migration, will be, and in some cases already are, experiencing, adapting, and leading community adaptation efforts in response to the changing climate.

Perceptions influence how a community frames climate change, how its members evaluate the risks they face because of climate change impacts, and what adaptation choices its members ultimately make (Bone et al. 2011). It is important to document environmental changes observed by members of each generation to compile the most complete temporal and spatial record of environmental observations and to gain an understanding of the context, concepts, and vocabulary used by different generations

\footnotetext{
${ }^{1}$ National Research Program, U.S. Geological Survey, ${ }^{2}$ University of Montana, ${ }^{3}$ Ecosystem Science and Sustainability, Colorado State University, ${ }^{4}$ Geospatial Centroid, Colorado State University, ${ }^{5}$ Alaska Science Center, U.S. Geological Survey, ${ }^{6}$ Alaska Climate Science Center, ${ }^{7}$ Science Department, Yukon River Inter-Tribal Watershed Council, ${ }^{8}$ Rocky Mountain Research Station, U.S. Forest Service
} 
to talk about climate and its changes. We present research that took place within the context of an interdisciplinary project, Strategic Needs of Water on the Yukon (SNOWY; HermanMercer and Schuster 2014). SNOWY was an exploratory project focused on investigating how communities in the Lower Yukon River Basin (LYRB) and Yukon-Kuskokwim (YK) Delta region understand climate change and interact with their environment combined with the collection of physical science data. We focus on the findings from semistructured, open-ended interviews conducted in four Subarctic Alaskan communities during the winter of 2014. The authors have been working with these communities since 2009 on various projects on which this research builds.

By gaining an understanding of how a community observes and perceives climate change impacts, we can begin to estimate the vulnerability and resiliency of that community. We define "observations" as specific examples of landscape and weather change, such as an increase in rain during winter months, whereas "perception" refers to how these observations of change are understood and explained. Distinct perceptions between generations emerged during our interviews and merit further research and consideration of how differing environmental perceptions may influence the development of adaptation strategies in these communities.

\section{Background}

\section{The region and its people}

The villages of our study area, St. Mary's, Pilot Station, Kotlik, and Chevak, are located in the LYRB and the YK Delta region (Fig. 1). St. Mary's and Pilot Station are riverine communities located along the Yukon River; Kotlik and Chevak are located along tributaries of the Yukon River in coastal areas. St. Mary's, Pilot Station, and Kotlik are Yup'ik communities, whereas Chevak is a Cup'ik community whose residents speak the Cup'ik dialect of the central Yup'ik language and identify as a distinct population. According to the 2010 U.S. Census, the populations of St. Mary's, Pilot Station, Kotlik, and Chevak are 507, 568, 577 , and 938, respectively (U.S. Census Bureau 2010a).

The landscape of the Yukon River Basin has diverse physiography, climatology, and ecology, which present both opportunities and challenges to the largely subsistence-based residents of the basin. Only a few vehicular arteries connect the area, and much of the basin is roadless. The Yukon River serves as a major transportation conduit for barges, riverboats, and snowmobiles and, to a lesser degree, for dogsleds, kayaks, and canoes. The river provides livelihood to the residents of the basin in the form of food, transportation, water, firewood, and building supplies. Over the past 60 years in Alaska, Bieniek et al. (2014) found a $1.7^{\circ} \mathrm{C}$ increase in mean annual temperatures. Increased temperature will likely change water chemistry, alter permafrost distribution (Jorgenson et al. 2006, Romanovsky et al. 2008, Frey and McClelland 2009), increase glacier melt, increase discharge, and alter inputs to the eastern Bering Sea (Walvoord and Streigl 2007, Walvoord et al. 2012). All of these changes have the potential to affect human existence and biophysical processes and roles in the basin.
Fig. 1. Study area.

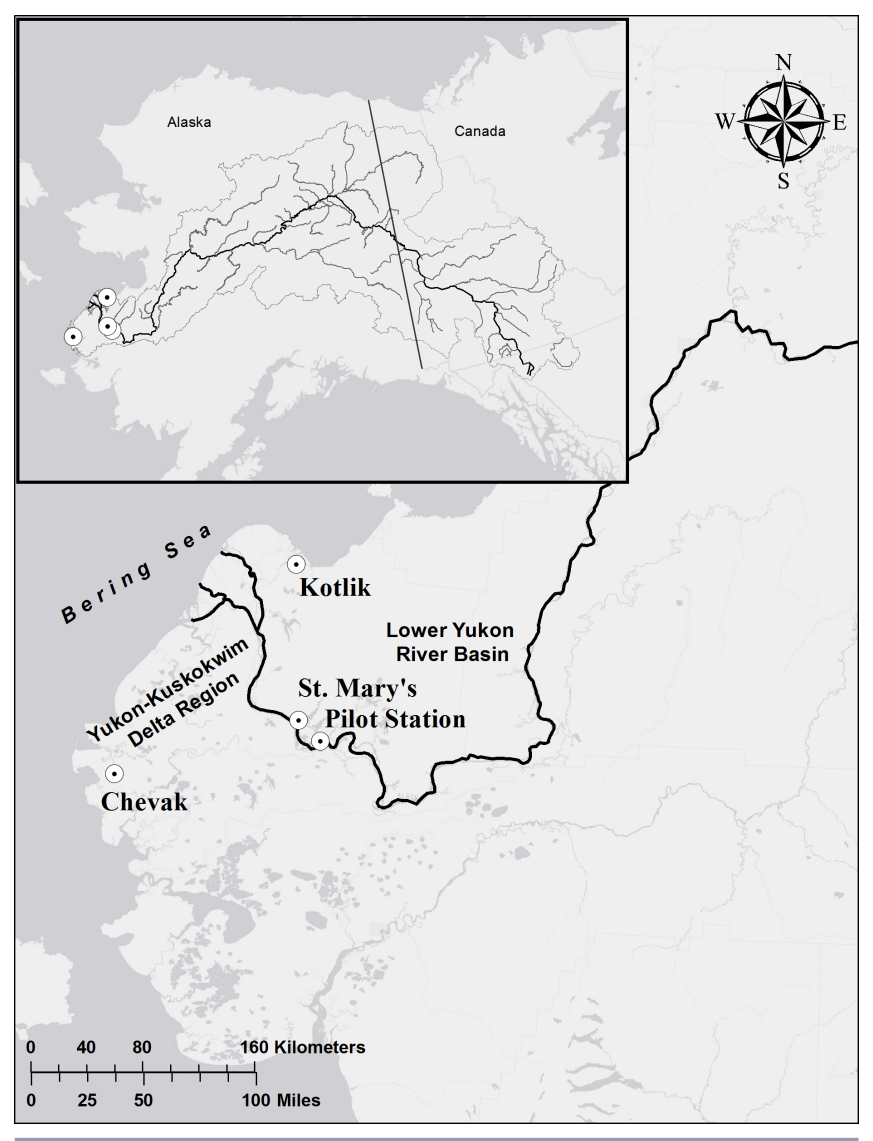

In addition to climatological changes in the LYRB and YK Delta region, these communities have undergone rapid social change over the past 40 years. The Yup'ik and Cup'ik elders of today were raised in a time of transition, born before Alaskan statehood and when many in the community lived in sod houses without running water or electricity. As one interview participant stated when speaking about her mother, "Yeah my mom would say she didn't really live in a house until after she got married. So they went from living in a sod house to a house. No electricity to electricity. No running water to running water" (Ruth Ulroan, cohort 2, Chevak $\left.{ }^{[1]}\right)$. Presently, the villages in this region are characterized by modern homes filled with appliances including computers and televisions. They are more connected to the outside world than they were just 30 years ago. As a participant (cohort 3) from St. Mary's illustrates, "The only white people we ever saw were teachers and nobody else ... we didn't know there was an outside world. I didn't know there was an outside world." Currently, many residents, particularly the younger generations, have smart phones. Many homes are connected to the Internet and have satellite television. The youth of the communities have a greater degree of connectivity because the schools typically have the best Internet connection in the village. Students have access to the latest information and technology advances. The Lower Yukon School District (LYSD) website boasts, "LYSD's robust technology infrastructure is among the best in Alaska" (http:// 
loweryukon.org/menu/about/). This transformation of technology and connectivity, transitioning from sod homes without electricity to modern homes with satellite television over the past 30 to 40 years, happened in a much shorter time frame in most Alaskan villages than in the rest of the United States.

The historical Yup'ik and Cup'ik way of life was dominated by seasonal movement to various subsistence-based camps. Seasonally available resources were gathered from the surrounding landscape with families camping at these locations for weeks or months at a time. A participant describes how his parents subsisted off the land: "Seasonal camps is what they did, they'd follow where the food is, like in the fall time there is a lot of blackfish and trapping for mink and muskrat and in the winter, we'd follow along with fish nets and then in the spring time they'd go to the coast and camp right at the coast and hunt the seals and the birds that were coming in and belugas and walrus. Summer time they would move inland and fish for salmon to start the process over again and follow where the food is" (cohort 2, Chevak). Subsistence hunting, fishing, trapping, and gathering are still staple activities in these communities. However, fewer people participate than in the past. Modern, faster modes of transportation often allow people to return home after subsistence excursions rather than camping for extended periods of time. Additionally, each community has at least one local grocery store, which is increasingly supplementing locally hunted and gathered resources.

The customary Yup'ik and Cup'ik worldview is of a reciprocal relationship between humans and the environment. FienupRiordan (1986:29) describes the Yup'ik and Cup'ik worldview of a reactive environment in the context of past and potential natural disasters disrupting subsistence harvesting:

For the Yup'ik harvest disruptions accomplished by means of a natural disaster were not perceived as arbitrary or externally imposed events. On the contrary, they were the result of an infraction in the elaborate code of interaction between man and the natural environment. High water and freezing weather, along with the hardships and famine that attended them, were caused by human misdeed, not arbitrary chance.

Human action or inaction, thought, and deed are seen as powerful influences on the landscape, environment, and weather. Yup'ik and Cup'ik storytelling features cautionary tales of historical famine and harvest disruption caused by human actions and the importance of dutifully following codes of conduct to survive during times of hardship (Fienup-Riordan 1986). In these stories, the health of society and the environment are inseparable. To understand the current relationship between the people and the environment in communities of the LYRB and YK Delta regions, in the context of ongoing climate change impacts, we visited these villages to ask community members about their observations of changes, seasonal interactions and relationship with the environment, and the context within which they understand these changes and relationships.

\section{METHODS}

Semistructured interviews were conducted in the villages of St. Mary's, Pilot Station, Kotlik, and Chevak, Alaska, over the course of three and a half weeks in February 2014. Interview participants were recruited in three ways. First, our local partners and facilitators recruited participants they believed to be experts in their community who were also willing to participate in our study. Second, a community dinner was held the first evening we were in each village, with the exception of Pilot Station. At this dinner, the research team was introduced, a brief presentation was given about the project, and community members were encouraged to participate. Third, a snowball sampling technique was utilized, allowing interview participants to recommend other community members as interview candidates, and we encouraged participants to tell others about the interviews. In May and August 2014, we returned to the communities to validate the accuracy of preliminary results and community products with participants.

The interviewers in this project have spent extensive time in the communities conducting fieldwork for other projects and outreach for this research. All interviewers utilized a common question guide to facilitate the comparability of results between interviews. The question guide was composed of open-ended questions regarding seasonal changes, weather patterns and change, and subsistence activities of each season (Appendix 1). The goal of this research was to understand the community's relationship to the environment, the seasonality of this relationship, and climate change impacts that may be affecting the community. However, to understand to what the interview participants themselves ascribed any observations of environmental change, we refrained from using the term "climate change" in the outreach leading up to the project, community dinners, and in the interviews themselves. Avoiding the term "climate change" in this research was a conscious and deliberate decision made to avoid presupposing that any observation of change made by the interview participants was because of the effects of climate change or limiting the interviewee responses to only the observations they ascribed to climate change. By consciously avoiding the term "climate change" we believe that we were better able to extrapolate how the participants themselves made sense of the cause of observed environmental changes communicated to us. The interviews were audio recorded, transcribed verbatim by the University of Idaho Social Science Research Unit, and coded in NVivo 10 for Windows ${ }^{[2]}$ (QSR International; http://www.qsrinternational.com/products nvivo. aspx). Codes were developed a priori as derived from the interview question guide and inductively from recurring, unanticipated themes that arose in the interviews (Schwandt 2007).

Following common generational divisions in the United States (Novak 2016), we split the interview participants into 4 distinct age cohorts during the analysis: cohort 1, ages 18-29, the millennial generation, hereafter referred to as young adults; cohort 2, ages 30-49, generation X; cohort 3, ages 50-64, baby boomers; and cohort 4, ages 65 and older, 65 being the age at which one becomes an elder in these communities. A similar generational division has been used by Wexler (2014) following the differing social environments participants experienced in their formative years. For instance, elders were raised at a time when people still spent much of the year moving between seasonal camps and spent the rest of the year in sod houses. Baby boomers were raised when children in the communities were often removed from their homes to attend boarding schools at regional centers within the state and outside of Alaska. Members of generation 
Table 1. Common observations across all age cohorts and communities.

\begin{tabular}{|c|c|c|}
\hline Season & Observation & Example from Interview \\
\hline \multirow[t]{6}{*}{ Winter } & Warmer temperatures & "Even if we say it's cold, it's not cold like it used to, it's getting warmer." \\
\hline & Increasing wind & $\begin{array}{l}\text { "Even piece of grass from the frost, used to build, buildup frost that thick. One grass sticking out from } \\
\text { the snow, hardly any wind. Nowadays we don't see frost on the roofs our grass that sticking out from } \\
\text { the snow, we don't see frost. More winds nowadays because the weather's changing." }\end{array}$ \\
\hline & Decrease in snow & "It's been like quite a while since we had those big snow drifts." \\
\hline & Increase in rain & "Not when I was younger, but in the past 10 years we've seen rain in the winter." \\
\hline & Increased weather variability & $\begin{array}{l}\text { "It's not a consistent cold like we used to have. It kind of fluctuates and so we'd have like a spell of } \\
\text { cold weather." }\end{array}$ \\
\hline & Shift of seasonal time frames & "The winters are coming in later and later." \\
\hline Spring & Shift of seasonal time frames & $\begin{array}{l}\text { "We had longer springs and I think the fish go under the ice or something you know and we're not } \\
\text { catching as many fish." }\end{array}$ \\
\hline \multirow[t]{3}{*}{ Summer } & Colder temperatures & $\begin{array}{l}\text { "The last few summers have been cool. Cool summers. I notice it's always been cold to go out by boat } \\
\text { and travel." }\end{array}$ \\
\hline & Increased rain & $\begin{array}{l}\text { "We seem to have more rain in the spring and early summer it seems like. We used to back in those } \\
\text { early years, spring used to be perfect and early summer used to be perfect and nowadays seems like we } \\
\text { get to see rain more often than before." }\end{array}$ \\
\hline & Shift of seasonal time frames & "Even the floods and rain come early now." \\
\hline \multirow[t]{2}{*}{ Fall } & Later freeze-up & $\begin{array}{l}\text { "Yeah you know when the kids go out trick or treating in October they usually cross the river ... this } \\
\text { year they didn't get to. How many years now, maybe two or three years they haven't been doing that." }\end{array}$ \\
\hline & Shift of seasonal time frames & "The fall time is much longer than it usually is." \\
\hline
\end{tabular}

$\mathrm{X}$ were able to attend school in their home village and were raised when modern homes with running water and electricity were becoming the norm. Finally, the millennial generation in Alaska parallels that of millennials in the rest of the United States. They have been raised in a social environment of the greatest connectivity to the rest of the world. Figure 2 shows the total number of interview participants and a breakdown by community, region, and age cohort. After the initial coding, interviews were further analyzed by sorting observations of change from the coded text by age cohort and community.

Fig. 2. Interview participants by community, age, and region.

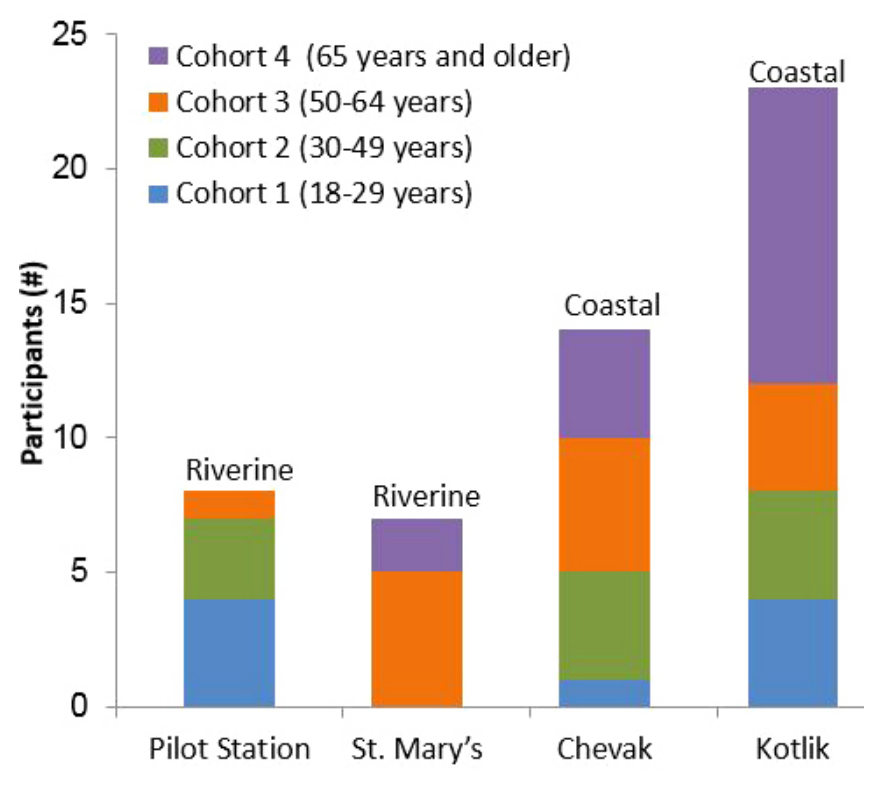

\section{Limitations}

Recruitment of participants relied heavily on our community partners and the success of the community dinners. This resulted in uneven samples of the population regionally and within the villages. As Figure 2 highlights, the number of interview participants in St. Mary's and Pilot Station were small ( $\mathrm{n}=7$ and $\mathrm{n}=8$, respectively). Additionally, the participants in these communities were skewed by age cohort. In St. Mary's, 5 of the 7 participants were aged between 50 and 64 years (cohort 3), and no participants were younger than 50. Conversely, in Pilot Station, half of the interview participants were between the ages of 18 and 29 (cohort 1) and only 1 participant was 50 years or older. Additionally, snowball sampling resulted in a disproportionate number of participants from 1 or 2 families. However, members of 1 family were also members of different age cohorts. Despite these limitations, saturation was reached because interviewees from the same age cohorts yielded similar information over time.

\section{RESULTS}

Although the goal of our research was not to discover generational differences in the communities we visited, it became clear throughout the interview, coding, and analysis processes that differences existed between the generations in both observations and perceptions of climate change. Among our interview participants, our research found that intergenerational observations of environmental changes were common in all four communities, and more changes were observed during summer and winter than in spring and fall. Furthermore, observations and perceptions of change differed between generations. Our results, presented subsequently, are organized around the themes of observations of change and perceptions of change of four different age cohorts. Observations of change are divided into a discussion of observations that were common among all generations, i.e., intergenerational observations, and those observed by specific age cohorts, i.e., generational observations. The generational observations are further divided by season- 
specific observations. Perceptions of change are then presented as a comparison between different age cohorts.

\section{Observations of change}

\section{Intergenerational observations}

It's changing. The climate change is changing in Alaska. Anonymous, cohort 3, Kotlik

Changing climate observations were communicated by participants belonging to all age cohorts and in all communities. The most common of these observations are illustrated in Table 1. Although observations of change were conveyed for all seasons, nearly twice as many specific observations of change were noted for the seasons of winter and summer than the transitional seasons of spring and fall (Table 2). For all seasons, observations are consistent in referring to increased weather variability and unpredictability. This is especially apparent in the observation made by participants that the time frames of seasons are shifting. This shift was communicated as a change in the time when the season begins and ends and accompanying weather, plant, and animal patterns happening earlier or later than expected. "It seems like when I was younger, smaller, it would be not until June that we would start seeing the green and everything turning green, but it seems like now it starts in May. It seems to me everything is a month earlier" (anonymous, cohort 3, St. Mary's).

Table 2. Intergenerational observations of change by season.

\begin{tabular}{lcc}
\hline \hline Season & $\begin{array}{c}\text { Number That Observed } \\
\text { Change/ } \\
\text { Total Number of } \\
\text { Participants }\end{array}$ & $\begin{array}{c}\text { Percent of Participants } \\
\text { That Observed Change }\end{array}$ \\
\hline Winter & $35 / 51$ & 69 \\
Spring & $15 / 51$ & 29 \\
Summer & $30 / 51$ & 59 \\
Fall & $12 / 51$ & 24 \\
\hline
\end{tabular}

Although the majority of observations were in regard to winter and summer, shifting time frames were spoken of in regard to spring and fall. Interview participants' spoke of how the spring and fall seasons are lengthening, extending into summer and winter making the transitional seasons seem longer and the changes in summer and winter seem more extreme. Seasons were referred to in terms of being "stretched." In a translated interview conducted in Cup'ik, the translation reads, "Like it's supposed to happen in this month and it has furthered later on and when it's supposed to freeze it doesn't freeze, but does it later on.' Almost like he said the months stretched" (anonymous, cohort 4, Chevak).

\section{Generational observations}

Throughout the course of this project, it became apparent that interviews with elders and young adults followed very different patterns. Interviews generally began by asking the question, "Can you tell me what a typical winter is like?" Interview participants belonging to cohort 4 (elders) answered by describing the changes they have observed in recent years from what they considered a typical winter and by describing what the winters of their youth were like, frequently referring to them as "real winters." For example, one elder answered, "It's really different from years back, how the weather looks right now" (anonymous, cohort 4, Kotlik). In contrast, the young adults interviewed gave fairly precise descriptions of a typical winter based on temperature and snowfall amounts when asked what a typical winter was like: "Averaging like 10 to 20 degrees Fahrenheit, 10 to 20 inches of snow. That's pretty typical" (anonymous, cohort 1, Kotlik).

While interviewing those in cohort 1 , the youngest cohort, direct questions about change were required before changes in seasonal and weather patterns were described. Elders, however, began by discussing these changes before they were asked specifically about change: "Usually have early freeze up, Septembers at the time when we moved here. And then we expect that every year, late September or early October when it usually freezes over. Then as the years go on the freeze up started to get later and later. Nowadays it freezes up end of October, sometimes November" (anonymous, cohort 4, Kotlik). Similarly, interview participants in cohorts 2 and 3 described changing weather patterns without being directly asked about change: "I've noticed that since the 1960s the winters have become shorter and the snow depths have become less" (anonymous, cohort 3, St. Mary's). Not only did those interviewed from cohort 1 require the use of direct questioning, but they also related fewer observations of change overall than those belonging to any other cohort interviewed. Generally, cohort 1 interviewees described the weather as variable: "I think every summer's the same. Just sometimes starts late, sometimes starts early" (anonymous, cohort 1, Chevak). In addition to fewer observations of change in interviews with those of cohort 1 , there is variation between the generations in what is considered typical for a particular season. For example, participants from cohort 1 described freezing temperatures as arriving in November: "The typical winter would be starting November with the freezing temperatures and the beginning of the snow" (anonymous, cohort 1, Kotlik). Those belonging to cohort 4 stated that freeze-up should begin in late September or early October. Only one interview participant from cohort 1 mentioned shifting seasonal time frames, whereas elders focused extensively on changing time frames. To further explore this variation, interviews were coded by season, age cohort, and description of change for particular seasons. The results of this coding are described subsequently.

Winter: There is a notable difference in the number of observations of change in winter weather related by cohorts 1 and 4 , with only 2 participants from cohort 1 describing change as opposed to 14 participants belonging to cohort 4 (Table 3).

Table 3. Observations of changing winter conditions by age cohort.

\begin{tabular}{lcc}
\hline \hline $\begin{array}{l}\text { Age } \\
\text { Cohort }\end{array}$ & $\begin{array}{c}\text { Number of } \\
\text { Participants }\end{array}$ & Percent of Participants \\
\hline $1(18-29)$ & $2 / 9$ & 22 \\
$2(30-49)$ & $7 / 11$ & 64 \\
$3(50-64)$ & $12 / 15$ & 80 \\
$4(65$ and older $)$ & $14 / 16$ & 88 \\
\hline
\end{tabular}

The winter these interviews were conducted was characterized by unusual weather. In our study area, the winter of 2013-2014 was marked by a distinct lack of snow, warmer than usual 
temperatures, and unusual winter rain storms (NOAA NCEI 2014). In an attempt to remove bias from interview responses, observations of the strangeness of the winter of 2013-2014 were coded separately from observations of overall winter change. However, our results reveal that observations of changing weather patterns were more prominent in the winter season than in any other season. The impact this unusual winter had on participant responses cannot be known in any precise way, but efforts were made while conducting interviews to acknowledge the weather outside and encourage participants to think about longer term weather trends. Therefore, stating that the young adult cohort of interview participants observed less change is not to say that they were unaware of the unusual weather of that winter, because they remarked on the warm temperatures and lack of snow at a rate similar to other cohorts we interviewed.

Interview participants belonging to cohort 1 observed an increase in rain and a decrease in snow for the season of winter. Other cohorts interviewed observed warmer temperatures (cohorts 2-4), a shift in the season's time frame (cohorts 2-4), increased weather variability (cohorts 3-4), and changes in the patterns of wind and freezing (cohort 4). Compared to the other cohorts interviewed, only a small percentage of young adults interviewed directly communicated observing changes to the winter season, as illustrated in Table 3.

Summer: Observations of change in the summer season followed a different pattern than observations about winter across age cohorts interviewed. A similar percentage of cohort 1 and cohort 4 observed changes in the summer months (Table 4 ), whereas the greatest percentage of observations was made by individuals belonging to cohort 2 . In the summer season, all age cohorts observed both warmer and colder temperatures, i.e., greater observed temperature range or variability, as well as an increase in clouds and rain. However, only those from cohorts 2, 3, and 4 observed a decrease in rain, a shift in the season's time frame, and an increase in wind.

Table 4. Observations of changing summer conditions by age cohort.

\begin{tabular}{lcc}
\hline \hline $\begin{array}{l}\text { Age } \\
\text { Cohort }\end{array}$ & $\begin{array}{c}\text { Number of } \\
\text { Participants }\end{array}$ & Percent of Participants \\
\hline $1(18-29)$ & $4 / 9$ & 44 \\
$2(30-49)$ & $9 / 11$ & 82 \\
$3(50-64)$ & $9 / 15$ & 60 \\
$4(65$ and older $)$ & $8 / 16$ & 50 \\
\hline
\end{tabular}

Spring and fall: Only one cohort 1 participant observed a change in typical weather patterns for fall; this observation was of a shift in the season's time frame. A shift in the season's time frame was observed by every cohort, though more individuals in cohort 4 observed this than any other cohort. The majority of the observations of change during the season of fall were observed by those in cohort 4 (Table 5). Cohort 1 observed warmer temperatures and later green-up in spring. No other age cohorts communicated these particular observations. The majority of observations of change to spring weather were made by those in cohort 3 (Table 6).
Table 5. Observations of changing fall conditions by age cohort.

\begin{tabular}{lcc}
\hline \hline Age & $\begin{array}{c}\text { Number of } \\
\text { Participants }\end{array}$ & Percent of Participants \\
Cohort & $1 / 9$ & 11 \\
\hline $1(18-29)$ & $2 / 11$ & 19 \\
$2(30-49)$ & $2 / 15$ & 13 \\
$3(50-64)$ & $7 / 16$ & 44 \\
$4(65$ and older $)$ & &
\end{tabular}

Table 6. Observations of changing spring conditions by age cohort.

\begin{tabular}{lcc}
\hline \hline Age & Number of & Percent of Participants \\
Cohort & Participants & \\
\hline $1(18-29)$ & $1 / 9$ & 11 \\
$2(30-49)$ & $3 / 11$ & 19 \\
$3(50-64)$ & $7 / 15$ & 47 \\
$4(65$ and older $)$ & $4 / 16$ & 25 \\
\hline
\end{tabular}

\section{Perceptions of change}

The world is getting thin. - Anonymous, cohort 4, Kotlik

Seems like global warming is affecting the permafrost. - Casey Matthias, cohort 1, Kotlik

Climate change observations made by elders in our interviews were frequently in reference to predictions made in their youth by their own elders. More than 50 percent of interview participants belonging to cohort 4 brought up, without being directly questioned, that their elders had predicted the weather changes that they are now living through. "My grandma used to say in the future we will have no more snow and down states [referring to the contiguous United States] they'll be like us and they'll be suffering, they wouldn't be used to winter cold" (anonymous, cohort 4, Chevak). Although cohort 4 most frequently discussed environmental change predictions made by their elders, participants in cohorts 2 and 3 were also aware of these predictions and referenced them when describing changes that they had experienced. However, none of the younger interview participants belonging to cohort 1 described these predictions.

It is unclear whether the youngest interviewees (cohort 1) were unaware that their ancestors made these predictions or whether they were aware of the predictions but did not see them as relevant to a discussion of current weather patterns in the context of our interviews. As a participant from cohort 2 (Chevak) states, "But our younger generation, those younger than us, they don't hear these stories anymore. It's like a fairy tale, they might know it's real, but it doesn't hit them as the way it got to us." There is a marked absence in reference to elders' prediction of climate change within the young adult population interviewed (Table 7).

Many of the aforementioned elder predictions involved not only environmental changes but also social changes. One elder spoke of his great grandmother in the following manner:

She knew what was going to happen. And then we look at it and when I see things I guess, my great grandma or other people says 
Table 7. Number of times elder-predicted change was spoken of by each age cohort.

\begin{tabular}{|c|c|c|c|c|c|}
\hline Prediction & Example & $\begin{array}{c}\text { Cohort } 1 \\
(18-29 \text { Years })\end{array}$ & $\begin{array}{c}\text { Cohort } 2 \\
(30-49 \text { Years })\end{array}$ & $\begin{array}{c}\text { Cohort } 3 \\
\text { (50-64 Years) }\end{array}$ & $\begin{array}{c}\text { Cohort } 4 \\
(65 \text { Years and } \\
\text { Older) }\end{array}$ \\
\hline $\begin{array}{l}\text { The weather is } \\
\text { following its people }\end{array}$ & $\begin{array}{l}\text { "But I used to hear the story behind this, our elders } \\
\text { used to say, in the near future our weather } \\
\text { continuously start being bad, following the people." } \\
\text { (Chevak) }\end{array}$ & 0 & 1 & 0 & 3 \\
\hline $\begin{array}{l}\text { Our ancestors said the } \\
\text { weather would change }\end{array}$ & $\begin{array}{l}\text { "Yeah well our ancestors said the weather's going } \\
\text { to change." (Pilot Station) }\end{array}$ & 0 & 1 & 2 & 8 \\
\hline $\begin{array}{l}\text { Get ready for needy } \\
\text { times }\end{array}$ & $\begin{array}{l}\text { "Anybody can notice what's happening, but some } \\
\text { elders are telling us, very old elders, that we are } \\
\text { living in times when we should be getting ready for } \\
\text { needy times." (Chevak) }\end{array}$ & 0 & 0 & 1 & 2 \\
\hline $\begin{array}{l}\text { Lower } 48 \text { states and } \\
\text { Alaska will switch } \\
\text { weather }\end{array}$ & $\begin{array}{l}\text { "He said pretty soon Alaska will have California } \\
\text { weather and pretty soon our winters will not be } \\
\text { winter." (St. Mary's) }\end{array}$ & 0 & 0 & 2 & 2 \\
\hline $\begin{array}{l}\text { It is a cycle of which } \\
\text { our elders spoke }\end{array}$ & $\begin{array}{l}\text { "For example, when they go someplace they always } \\
\text { come back again. That's what the old man was } \\
\text { saying." (Kotlik) }\end{array}$ & 0 & 0 & 1 & 4 \\
\hline $\begin{array}{l}\text { Elders paid more } \\
\text { attention to Mother } \\
\text { Nature }\end{array}$ & $\begin{array}{l}\text { "These guys know. They pay attention to mother } \\
\text { nature. They knew what was going to happen." } \\
\text { (Kotlik) }\end{array}$ & 0 & 1 & 1 & 2 \\
\hline
\end{tabular}

what's happening and they were right! Like someday we'd be talking to somebody out states. We'd be talking with them how? You don't know. We find out it's a phone. We talk by phone. (Raymond Teeluk, cohort 4, Kotlik)

The elders interviewed shifted from speaking about changes in the weather and landscape to social changes without being directly questioned about social changes. Elders described an environment of change that was observable in the weather and in society. The Yup'ik and Cup'ik worldview that holds that the environment is responsive to human thought, action, and deed is the context within which the elders of our study understand and describe the climate change impacts they are witnessing, whereas this social-ecological connection went entirely unmentioned by cohort 1 interview participants. The following translated interview excerpt demonstrates the Yup'ik and Cup'ik belief that human action is essential in maintaining environmental and subsistence harvest predictability:

Long ago you know how they used to go out camping ... since they stopped doing that and since they stopped going by dog team and where they'd get to, as far as like a whole lot of fish, they would catch really lots, since they don't go, it seems like the fish are more scarce and harder to get. (Cecilia Andrews, cohort 4, Chevak).

Another participant describes how the absence of harvesting subsistence resources can affect the people: "From listening and talking with the elders in this village, they say that the eels are indicators of - when they're not being harvested by the locals in their village - that it's an indicator that a death will occur. So when they bypass here and are not caught by locals, it's an indicator. And it's always been true" (anonymous, cohort 3, St. Mary's).

In contrast to the social-ecological relationship described by their elders, younger participants interviewed (cohort 1) referenced climate change and natural disasters to explain changes in weather patterns, landscapes, and subsistence resources. For example, when describing a major flood event experienced in Kotlik in November 2013, one cohort 1 participant attributed higher water in the slough that runs through their village to global warming:

It seems like over the years the water has been getting higher and higher. This past summer when they told me that the water was coming up, they said it hardly used to be like that ... Sounds like it's getting higher and higher, the water level. With all this global warming too, the glaciers melting away and melting more water into the ocean. (Casey Matthias, cohort 1, Kotlik)

Furthermore, interview participants of younger generations ascribed lower populations of game animals to natural disasters:

When I was growing up I used to walk across the river right here to the other side of the island and go look for a few rabbits, but nowadays they go check back there and there's nothing, no rabbits. I think all the flooding wiped them out totally. You have to go to the high ground or to the hills to look for rabbits. (Anonymous, cohort 1, Kotlik)

Elder participants and one participant from cohort 2 described the weather as following its people. This adage is not unique to our work, because it was identified through previous research with the Calista Elders Council (Fienup-Riordan 2010, FienupRiordan and Rearden 2012). In our study, this concept of change was described as the weather changing because culture was changing. The youngest cohort interviewed, on the other hand, stated that fluctuating weather patterns were normal and that global warming could be attributed to changes in natural resources. The differences in the way the weather and the seasons were spoken of by interview participants belonging to different age cohorts points to a difference in the way that they make sense of these observations: a difference in perception.

\section{DISCUSSION}

It is clear from our interview data that environmental changes are being observed by interview participants of all generations in the 
region of this study. Among the interview participants, generations differ in what environmental changes they are observing and the context in which these observations are understood. The greatest variation in our study was in what is considered typical weather by those in cohorts 1 and 4 . This may be attributed to the fact that the 10 warmest years globally, in the instrumented record, have occurred since the year 2000. In fact, Arctic temperatures in the late 20th century were the highest they have been in the past 400 years (Overpeck et al. 1997). Looking specifically at the maritime Arctic, Polyakov et al. (2003) determined that a mean temperature increase of $1.2^{\circ} \mathrm{C}$ had occurred between the years 1875 and 2000. Bieniek et al. (2014) found a mean temperature increase of $1.7^{\circ} \mathrm{C}$ between 1949 and 2012 specifically in Alaska with winter and spring temperatures having the largest increases (Wendler et al. 2012). Additionally, temperature increases started in Alaska around 1977 with a high correlation to the Pacific Decadal Oscillation (Hartmann and Wendler 2005). Given the time frame of increased temperatures in the Arctic, we can assume that the entire life span of cohort 1 is represented by the Arctic warming trend. Those belonging to other age cohorts, especially those in cohort 4, likely have memories of weather patterns before this warming trend began. With respect to these cohorts, other climate studies in Alaska track natural decadal variations that characterized a 20 -year warmer period starting in the 1920s that switched to a colder period in the mid-1940s and lasted for 3 decades (Overland et al. 1999, Wendler et al. 2012).

The time frame of rising Arctic temperatures present in the instrumented record is referenced in statements made by interview participants of older cohorts in terms of changing weather patterns: "I haven't seen that accumulation of snow over the years since the late 70 s, early 80 s. It seems like our winters have warmed up a lot" (anonymous, cohort 3, St. Mary's). As with those belonging to cohort 4, participants from cohorts 2 and 3 reported a high percentage of observations of change throughout all seasons. Interview participants belonging to cohorts 2,3 , and 4 make reference to a past that was not so unpredictable. In this regard, variable weather patterns are considered typical for those interview participants belonging to cohort 1 more so than for those belonging to other age cohorts. This is not to say that the young adults interviewed do not recognize weather extremes, such as those in the winter of 2013-2014, but that they are more accustomed to variability in seasonal weather.

How a phenomenon is observed and perceived by an individual informs the risk that they associate with that phenomenon. If weather variability and opportunistic subsistence harvesting are seen as the norm, then one is less likely to associate risk with these factors. Conversely, if an inability to harvest a resource equates to a tragedy befalling the community, such as the example of eels given previously, then one is more likely to be alarmed by a lack of subsistence resources. We do not assume that one cohort or the other is more correct in their observations or perceptions of the environment and landscape in their community. Indeed, we do not question the validity of any of the observations related to us. The way that one observes a phenomenon and the way that phenomenon is perceived depend on a variety of factors related to the individual's worldview and life experiences.

A key reason for documenting environmental change observations and perceptions in any setting is to aid in the development of adaptation strategies to reduce vulnerability to climate change impacts. Moser and Ekstrom (2010:22026) define adaptation as follows:

Adaptation involves changes in social-ecological systems in response to actual and expected impacts of climate change in the context of interacting nonclimatic changes. Adaptation strategies and actions can range from short-term coping to longer-term, deeper transformations, aim to meet more than climate change goals alone, and may or may not succeed in moderating harm or exploiting beneficial opportunities.

Problem identification is a key component in taking action, and the importance placed on various issues of adaption varies between individuals and depends on their worldview and perceived limits to responsibility (Grothmann and Patt 2005). One cannot begin to develop a strategy for adapting to climate change before knowing what impacts are taking place, what impacts are most important, and the cause of the impacts. There may be profound implications for adaptation if differences in observation and perception of climate change exist in a community. Indeed as Moser and Ekstrom (2010:22028) point out in their discussion of barriers to climate change adaptation:

Although the system of concern may produce signals of change, the actors, governance system, and larger context affect whether they are noticed and how they are interpreted. In terms of detecting the problem ... the existence of the signal may not be detected if, for example, the actor's mental model filters out the signal, if the individual is too busy or distracted to notice it or if the actor is too distant from the signal to take note.

The young adults from cohort 1 that participated in our study observe the weather as variable, likely because that is all they have ever known. The members of the cohort 4 elder generation that participated in our study have witnessed rapid social and environmental changes over their lifetime. The linked relationship of social and environmental change in the minds of the elders interviewed causes them to perceive different risks to the community associated with climate change than the young adults we interviewed do. For example, one participant from St. Mary's, quoted earlier, stated that when the community is unable to harvest eels a death will occur in the community. Eels are typically harvested at the end of October, and community members refer to them as "Halloween fish." Interview participants explained to us that the eels did not arrive when they were expected in the fall of 2013 and were not harvested in St. Mary's. The same fall, the village of St. Mary's experienced its first fatal plane crash, which deeply affected the community. These two episodes are linked in the minds of some participants. For them, a change in the timing of resources such as eel poses not only a risk in terms of diet, but also a risk of death that may affect the entire community.

Our research found that the worldview of elders that participated in our study is one in which human actions and thoughts can affect the environment, landscape, and subsistence resources. This worldview places a great deal of responsibility on human action in terms of the changes that are being witnessed in these communities. However, young adults in our research did not relate as many observations of change and did not describe human responsibility when relating changes during interviews. Differing worldviews may lead to very different responses in terms of adaptation to change. For example, an elder quoted earlier spoke 
of fewer fish being harvested because of fewer people camping at that location. This is a central tenant of Yup'ik and Cup'ik traditional beliefs. As Fienup-Riordan (2000:19) puts it, "The Yup'ik explanation of hunting success and failure depend on proper social relations between humans and animals." A hunter that follows the Yup'ik and Cup'ik codes for living and hunting will be more successful than one who does not. Following this worldview to its logical conclusion, fish populations in this area will increase if people begin camping there again, as opposed to taking day trips to fishing locations. In contrast, young adults interviewed ascribe changes in subsistence populations to changes in the environment that are largely out of their control. Young adults, therefore, may feel less pressure to create a communitywide adaptation plan and instead employ individual adaptation strategies that involve being more flexible with the subsistence resources they harvest or being willing to travel farther distances.

The findings of our research highlight that IK surrounding environmental changes cannot be treated as a uniform body of knowledge. In fact, a person's age, experience, and connection to different knowledge systems greatly influences that individual's observations and perceptions about environmental change. As climate adaptation strategies are developed by these communities and for the region, it is imperative that these differences, i.e., generational in this research, be considered when formulating and implementing these plans. The challenge becomes how to combine the observations and perspectives and draw on the strengths of each generation provided by their unique worldviews. The adaptation strategy that a community chooses will come down to who is at the table and who defines the problem. Knowing that generations may see the problem differently means that, with the goal of having an adaptation method that is as accommodating and well rounded as possible, all groups must be involved in any adaptation decisions.

\section{NEXT STEPS}

Our research was conducted as an exploratory project to understand climate change observations and perceptions in this region. The differences between generations encountered in our research were not the focus of the project but provide much needed insight in terms of future adaptation strategies. It is clear that further research is needed to gain a better understanding of this occurrence. There are several concepts in existing literature that could be put forward as hypotheses to explain the differences in perceptions of change that we observed. We outline two such concepts, technology-induced environmental distancing (TIED) and shifting baseline syndrome (SBS). We propose that these concepts may provide a framework within which further research into the generational differences found in our study may be explored.

The concept of TIED put forth by Alessa et al. (2010) describes the process by which a community may become more vulnerable to climate change impacts as new technologies that satisfy basic needs, water resources in their example, are introduced (Alessa et al. 2010, Bone et al. 2011). The vulnerability lies in the fact that when basic needs are met by technology, instead of interactions with the environment, there is a loss of environmental awareness and thereby less awareness of environmental changes. However, as Bone et al. (2011) point out, this vulnerability may be mitigated through the transmission of IK.
In the region that our research was conducted, seasonal subsistence camps have been replaced with shorter day or weekend trips to accomplish subsistence harvesting. The exception to this is summer fish camp when salmon is harvested, which is still practiced by the majority of our interview participants. There are a variety of reasons why subsistence camps have disappeared, but conflicting school and work schedules, as well as faster modes of transportation via snowmobiles, have contributed. As one participant put it, "We used to stay overnight in the jigging sites, today you just zip over and zip right back because of our snow machines" (anonymous, cohort 3, Chevak). This shortening of time spent on the land to accomplish subsistence harvesting seems to fit well into the framework described by TIED. However, our study did not collect information on how much time individuals spent engaged in subsistence harvesting or how much of their diet was composed of subsistence resources. Without this information, we can only speculate on how much technology is influencing relationships with the environment and potentially changing perceptions.

An additional hypothesis for what we see in our interview data is the concept of SBS. SBS, as put forward in fishery studies by Pauly (1995), is defined by Papworth et al. (2009:93) as "changing human perceptions of biological systems due to loss of experience about past conditions." In the study of fisheries, SBS can be a dangerous condition in which each generation accepts a lower standard of fish abundance as normal, thereby shifting the baseline of fish populations and lowering conservation goals. Papworth et al. (2009) suggest that there are two types of SBS: (1) generational amnesia, in which knowledge extinction occurs because younger generations are not aware of past biological conditions, and (2) personal amnesia, in which knowledge extinction occurs as individuals forget their own experience. Additionally, Papworth et al. (2009) outline two key conditions that must exist to identify generational amnesia SBS: (1) biological change must be present in the system, and (2) if ageor experience-related differences are found, generational amnesia may be occurring provided that differences in perception are consistent with the biological data. In other words, if there is a documented change in the system and one generation's perceptions agree with the data whereas another's do not, then generational amnesia could be occurring and causing the baseline to shift.

Environmental change is present in this region and documented by climatological instrumentation and modeling (Overpeck et al. 1997), yet there exist generational differences in the observations and perceptions of this change among our interview participants. In terms of conservation, a shifting baseline can be dangerous; in climate change research, a shifting baseline may simply highlight real changes in the system. Understanding what each generation thinks typical weather patterns are may help researchers create a more temporally complete record of weather patterns where instrumental data are sparse.

Vulnerability induced by TIED and SBS are predicated on the assumption that IK of past environmental conditions is not being transmitted to the younger generations. Based on our data, it is unclear how much transmission of IK from older generations to younger generations occurs in these communities. Without further research into the question of knowledge transmission and 
interaction with the environment by different generations, there is no way to know if TIED or SBS is at play in this region. Furthermore, we cannot say with any certainty if either of these processes are causing the communities to be more vulnerable to climate change impacts.

Understanding the degree to which the different generations are communicating their observations and perceptions of environmental and landscape change to each other and via what mechanism is important and would further elucidate the generational differences we see in our data. Engaging young adults and elders in an intergenerational dialogue on climate change observations and perceptions may further illuminate differences or show points of consensus and overlap. Young adults interviewed did not speak of weather predictions that were made by their ancestors, whereas the majority of elders interviewed did. Learning whether young adults are aware of these predictions and, if so, what they make of them would increase our understanding of the worldview of the young adults. Additionally, investigating if there are differences between age cohorts in where subsistence resources are harvested and the length of time spent harvesting resources would help in understanding the degree to which subsistence harvesting has changed and if young adults are already employing adaptation strategies on an individual or family level in terms of subsistence harvesting. Furthermore, if technology is in fact influencing the environmental perceptions of young adults in this region, it might be worth investigating what this new social-ecological dynamic brings to the table in regard to climate adaptation. It seems possible that having a broader tool kit would aid in the flexibility required in the adaption process.

\section{CONCLUSION}

The lens through which climate change is viewed by younger generations that participated in this study is different from the perceptions of elders interviewed. Climate change impacts began in this region before cohort 1 was born. An environment of variability in weather, subsistence resources, and landscape is seen as the norm for young adults interviewed. Elders grew up during a time they describe as having relatively stable environmental patterns, and they were raised with an understanding of a fluid and reciprocal relationship with the environment. To them the weather, subsistence resources, and the landscape can be influenced by the actions, thoughts, and deeds of the people. The social landscape of the elders' generation, however, was one of rapid transformation and instability, and the climate in recent years has paralleled this trajectory. Therefore, it makes sense that elders would ascribe the environmental transformations they have witnessed to the rapid changes in society over their lifetime as "the weather following its people."

As we have outlined previously, the communities of this region have undergone rapid social changes. These social changes include the formal education system and changes in the way that subsistence activities take place with less emphasis on subsistence camps. Whether social changes are responsible for different environmental understandings between generations was beyond the scope of this work but could be a valuable focus of future research. The two concepts put forth previously, TIED and SBS, are reasonable hypotheses to explore in explaining the trends we see in our interview data. Combined with research on knowledge transmission in these communities, a deeper understanding of how climate change is perceived in this region could be developed. This understanding is essential for assessing a community's vulnerability and resilience to climate change impacts, which is the first step in creating strategies for adaptation.

The generational difference in both the observations and perceptions of climate change encountered in our study is contributing to an evolving way of understanding climate/ environmental variability and has implications for how adaptation strategies are developed in this region. It is only through understanding the observations and perceptions of climate change offered by all the generations in a community that policy makers can work with communities to develop and support successful strategies for adaptation. The stories that societies tell themselves and the rules for living that they create often have reallife survival mechanisms built into them. By understanding the nature of the social-ecological worldview that these rules and stories create, as well as the new rules for survival being written by today's younger generations, sustainable adaptation strategies may be created that utilize both the knowledge of the younger generations in combination with the invaluable lessons of cultural history.

${ }^{[1]}$ All interviews were conducted in February 2014 and are referenced within the text by name with permission or as anonymous if the respondent did not wish to be named in this publication. Participants are further referenced by age cohort and village.

${ }^{[2]}$ Any use of trade, firm, or product names is for descriptive purposes only and does not imply endorsement by the U.S. government.

Responses to this article can be read online at: http://www.ecologyandsociety.org/issues/responses. php/8463

\section{Acknowledgments:}

The authors would like to acknowledge the community members that participated in this study and thank them for taking time out of their busy lives to share their knowledge and experiences with us. We would also like to personally thank Cynthia Paniyak, Deborah Friday-Aguchuk, Victor Tonuchuk Jr., Tania Hunt, and Jay Hootch without the support of whom this project would not have been possible. The authors would also like to thank Julianne Fordyce, Eleanor Griffin, and the anonymous reviewers of this paper for their helpful comments. Finally, we would like to acknowledge the National Science Foundation (award number: 1118397), USGS Water and Climate and Land Use Change Mission areas for funding this research.

\section{LITERATURE CITED}

Adger, W. N., J. Bernett, K. Brown, N. Marshall, and K. O'Brien. 2013. Cultural dimensions of climate change impacts and adaptation. Nature Climate Change 3:112-117. http://dx.doi. org/10.1038/nclimate1666 
Alessa, L. N., A. A. Kliskey, and P. Williams. 2010. Forgetting freshwater: technology, values, and distancing in remote Arctic communities. Society \& Natural Resources 23(3):254-268. http:// dx.doi.org/10.1080/08941920802454813

Arctic Climate Impact Assessment (ACIA). 2005. Arctic climate impact assessment. Cambridge University Press, Cambridge, UK.

Beck, U. 2009. World at risk. Polity, Cambridge, UK.

Berkes, F. 1999. Sacred ecology: traditional ecological knowledge and resource management. Third edition. Taylor and Francis, London, UK.

Bieniek, P. A., U. S. Bhatt, R. L. Thoman, H. Angeloff, J. Partain, J. Papineau, F. Fritsch, E. Holloway, J. E. Walsh, C. Daly, M. Shulski, G. Hufford, D. F. Hill, S. Calos, and R. Gens. 2012. Climate divisions for Alaska based on objective methods. Journal of Applied Meteorology and Climatology 51:1276-1289. http://dx. doi.org/10.1175/JAMC-D-11-0168.1

Bieniek P. A., J. E. Walsh, R. L. Thoman, and U. S. Bhatt. 2014. Using climate divisions to analyze variations and trends in Alaska temperature and precipitation. Journal of Climate 27:2800-2818. http://dx.doi.org/10.1175/JCLI-D-13-00342.1

Bone, C., L. Alessa, M. Altaweel, A. Kliskey, and R. Lammers. 2011. Assessing the impacts of local knowledge and technology on climate change vulnerability in remote communities. International Journal of Environmental Research and Public Health 8:733-761. http://dx.doi.org/10.3390/ijerph8030733

Carothers, C., C. Brown, K. J. Moerlein, J. López, D. B. Anderson, and B. Retherford. 2014. Measuring perceptions of climate change in northern Alaska: pairing ethnography with cultural consensus analysis. Ecology and Society 19(4):27. http://dx.doi. org/10.5751/ES-06913-190427

Cruikshank, J. 2001. Glaciers and climate change: perspectives from oral tradition. Arctic 54(4):377-383. http://dx.doi. org/10.14430/arctic795

Fienup-Riordan, A. 1986. When our bad season comes: a cultural account of subsistence harvesting and harvest disruption on the Yukon Delta. Monograph No. 1, Alaska Anthropological Association, Anchorage, Alaska, USA.

Fienup-Riordan, A. 2000. Hunting tradition in a changing world: Yup'ik lives in Alaska today. Rutgers University Press, New Brunswick, New Jersey, USA.

Fienup-Riordan, A. 2010. Yup'ik perspectives on climate change: "the world is following its people." Études/Inuit/Studies 34 (1):55-70.

Fienup-Riordan, A., and A. Rearden. 2012. Ellavut, our Yupik world and weather: continuity and change on the Bering Sea coast. University of Washington Press, Seattle, Washington, USA; Calista Elders Council, Anchorage, Alaska, USA.

Fox, S. 2002. These are things that are really happening: Inuit perspectives on the evidence and impacts of climate change in Nunavut. Pages 12-53 in I. Krupnik and D. Jolly, editors. The earth is faster now: indigenous observations of Arctic environmental change. Arctic Research Consortium of the United States, Fairbanks, Alaska, USA.
Frey, K. E., and J. W. McClelland. 2009. Impacts of permafrost degradations on arctic river biogeochemistry. Hydrological Processes 23:169-182. http://dx.doi.org/10.1002/hyp.7196

Grothmann, T., and A. Patt. 2005. Adaptive capacity and human cognition: the process of individual adaptation to climate change. Global Environmental Change 15(3):199-213. http://dx.doi. org/10.1016/j.gloenvcha.2005.01.002

Hartmann, B., and G. Wendler. 2005. The significance of the 1976 Pacific climate shift in the climatology of Alaska. Journal of Climate 18:4824-4839. http://dx.doi.org/10.1175/JCLI3532.1

Herman-Mercer, N. M., and P. F. Schuster. 2014. Strategic needs of water on the Yukon: an interdisciplinary approach to studying hydrology and climate change in the Lower Yukon River Basin. Fact Sheet 2014-3060, U.S. Geological Survey, Denver, Colorado, USA. http://dx.doi.org/10.3133/fs20143060

Herman-Mercer, N., P. Schuster, and K. Maracle. 2011. Indigenous observations of climate change in the Lower Yukon River Basin, Alaska. Human Organization 70(3):244-252. http:// dx.doi.org/10.17730/humo.70.3.v88841235897071m

Hinzman, L. D., N. D. Bettez, W. R. Bolton, F. S. Chapin, M. B. Dyurgerov, C. L. Fastie, B. Griffith, R. D. Hollister, A. Hope, H. P. Huntington, A. M. Jensen, G. J. Jai, T. Jorgenson, D. L. Kane, D. R. Klein, G. Kofinas, A. H. Lynch, A. H. Lloyd, A. D. McGuire, F. E. Nelson, W. C. Oechel, T. E. Osterkamp, C. H. Racine, V. E. Romanovsky, R. S. Stone, D. A. Stow, M. Sturm, C. E. Tweedie, G. L. Vourlitis, M. D. Walker, D. A. Walker, P. J. Webber, J. M. Welker, K. S. Winker, and K. Yoshikawa. 2005. Evidence and implications of recent climate change in northern Alaska and other Arctic regions. Climatic Change 72(3):251-298. http://dx.doi.org/10.1007/s10584-005-5352-2

Jorgenson, M. T., Y. L. Shur, and E. R Pullman. 2006. Abrupt increase in permafrost degradation in Arctic Alaska. Geophysical Research Letters 33:L02503. http://dx.doi.org/10.1029/2005gl024960

Krupnik, I., and D. Jolly, editors. 2002. The earth is faster now: indigenous observations of Arctic environmental change. Arctic Research Consortium of the United States, Fairbanks, Alaska, USA.

Krupnik, I., and N. Vakhtin. 1997. Indigenous knowledge in modern culture: Siberian Yupik ecological legacy in transition. Arctic Anthropology 34(1):236-252.

Larsen, J. N., O. A. Anisimov, A. Constable, A. B. Hollowed, N. Maynard, P. Prestrud, T. D. Prowse, and J. M. R. Stone. 2014. Polar regions. Pages 1567-1612 in V. R. Barros, C. B. Field, D. J. Dokken, M. D. Mastrandrea, K. J. Mach, T. E. Bilir, M. Chatterjee, K. L. Ebi, Y. O. Estrada, R. C. Genova, B. Girma, E. S. Kissel, A. N. Levy, S. MacCracken, P. R. Mastrandrea, and L. L. White, editors. Climate change 2014: impacts, adaptation, and vulnerability. Part B, regional aspects. Contribution of Working Group II to the Fifth Assessment Report of the Intergovernmental Panel on Climate Change. Cambridge University Press, Cambridge, UK.

McNeeley, S. M., and M. D. Shulski. 2011. Anatomy of a closing window: vulnerability to changing seasonality in interior Alaska. Global Environmental Change 21:464-473. http://dx.doi. org/10.1016/j.gloenvcha.2011.02.003 
Moerlein, K. J., and C. Carothers. 2012. Total environment of change: impacts of climate change and social transition on subsistence fisheries in northwest Alaska. Ecology and Society 17 (1):10. http://dx.doi.org/10.5751/es-04543-170110

Moser, S. C., and J. A. Ekstrom. 2010. A framework to diagnose barriers to climate change adaptation. Proceedings of the National Academy of Sciences of the United States of America 107 (51):22026-22031. http://dx.doi.org/10.1073/pnas.1007887107

National Oceanic and Atmospheric Administration (NOAA) National Centers for Environmental Information (NCEI). 2014. State of the climate: national overview - February 2014. NCEI, Asheville, North Carolina, USA. [online] URL: http://www.ncdc. noaa.gov/sotc/national/2014/2

Novak, J. 2016. The six living generations in America. MarketingTeacher.com. [online] URL: http://www.marketingteacher. com/the-six-living-generations-in-america/

Nuttall, M. 2001. Indigenous peoples and climate change research in the Arctic. Indigenous Affairs 4/01:26-33.

Overland J. E., J. M. Adams, and N. A. Bond. 1999. Decadal variability of the Aleutian low and its relation to high-latitude circulation. Journal of Climate 12(5):1542-1548. http://dx.doi. org/10.1175/1520-0442(1999)012<1542:dvotal >2.0.co;2

Overpeck, J., K. Hughen, D. Hardy, R. Bradley, R. Case, M. Douglas, B. Finney, K. Gajewski, G. Jacoby, A. Jennings, S. Lamourex, A. Lasca, G. MacDonald, J. Moore, M. Retelle, S. Smith, A. Wolfe, and G. Zielinkski. 1997. Arctic environmental change of the last four centuries. Science 278:1251-1256. http:// dx.doi.org/10.1126/science.278.5341.1251

Papworth, S. K., J. Rist, L. Coad, and E. J. Milner-Gulland. 2009. Evidence for shifting baseline syndrome in conservation. Conservation Letters 2:93-100. http://dx.doi.org/10.1111/ j.1755-263x.2009.00049.x

Pauly, D. 1995. Anecdotes and the shifting baseline syndrome of fisheries. Trends in Ecology \& Evolution 10(10):430. http://dx.doi. org/10.1016/s0169-5347(00)89171-5

Polyakov, I. V., R. V. Bekryaev, G. V. Alekseev, U. S. Bhatt, R. L. Colony, M. A. Johnson, A. P. Maskshtas, and D. Walsh. 2003. Variability and trends of air temperature and pressure in the maritime Arctic, 1875-2000. Journal of Climate 16 (12):2067-2077. http://dx.doi.org/10.1175/1520-0442(2003)016\% 3C2067:VATOAT\%3E2.0.CO;2

Reidlinger, D., and F. Berkes. 2001. Contributions of traditional knowledge to understanding climate change in the Canadian Arctic. Polar Record 37(203):315-328. http://dx.doi.org/10.1017/ s0032247400017058

Romanovsky, V., G. Grosse, and S. Marchenko. 2008. Past, present, and future of permafrost in a changing world. Proceedings: Geological Society of America Abstracts with Programs 40(6):264.

Schwandt, T. A. 2007. The Sage dictionary of qualitative inquiry. Third edition. Sage, Thousand Oaks, California, USA. http://dx. doi.org/10.4135/9781412986281
Thomas, G. S. 2012. Population extremes: the youngest and oldest places in America. Business Journals, 31 August. [online] URL: http://www.bizjournals.com/bizjournals/on-numbers/scott-thomas/2012/08/ sumter-county-fla-has-oldest.html

U.S. Census Bureau. 2010a. American FactFinder. Community facts, 2010 Census. U.S. Census Bureau, Washington, D.C., USA. [online] URL: https://factfinder.census.gov/faces/nav/jsf/pages/ community facts.xhtml

U.S. Census Bureau. 2010b. American FactFinder. P12, P13, and PCT 12: age groups and sex, 2010 Census. U.S. Census Bureau, Washington, D.C., USA. [online] URL: https://factfinder.census. gov/faces/nav/jsf/pages/community facts.xhtml

Walvoord, M. A., and R. G. Striegl. 2007. Increased groundwater discharge from permafrost thawing in the Yukon River basin: potential impacts on lateral export of carbon and nitrogen. Geophysical Research Letters 34:L12402. http://dx.doi. org/10.1029/2007g1030216

Walvoord, M. A., C. I. Voss, and T. P Wellman. 2012. Influence of permafrost distribution on groundwater flow in the context of climate-driven permafrost thaw: example from Yukon Flats Basin, Alaska, United States. Water Resources Research 48: W07524. http://dx.doi.org/10.1029/2011wr011595

Wendler, G., L. Chen, and B. Moore. 2012. The first decade of the new century: a cooling trend for most of Alaska. Open Atmospheric Science Journal 6:111-116. http://dx.doi. org/10.2174/1874282301206010111

Wexler, L. 2014. Looking across three generations of Alaska Natives to explore how culture fosters indigenous resilience. Transcultural Psychiatry 51(1):73-92. http://dx.doi. org/10.1177/1363461513497417

Wilson, N. J. 2014. The politics of adaptation: subsistence livelihoods and vulnerability to climate change in the Koyukon Athabascan village of Ruby, Alaska. Human Ecology 42:87-101. http://dx.doi.org/10.1007/s10745-013-9619-3 
Appendix 1. Semi structured interview guide.

I thought that since it is winter right now we could start by talking about winter time...

\section{Can you tell me what a typical winter is like?}

When does it start to get cold?

When does it start snowing?

How much snow is typical in a year?

Does the snow melt or does it stick around until the spring after it has fallen?

What kind of snow do you typically get? Dry, wet, etc

What do you call that kind of snow?

Does different snow fall at different times of the year?

Does different snow fall in different places?

Do some areas get more snow than others?

Does it rain in the winter?

If so, how many times and is it becoming more frequent?

If so, does the rain freeze on top of the snow? When does the river freeze up?

Does it stay frozen all winter?

How thick does the ice get?

\section{Can you tell me about any winters you remember as not being typical?}

When was that?

How do you know when a winter is not typical?

Were the temperatures warmer? Colder?

Was there less snow? More snow? Different snow?

Changes in the timing of snow?

Have snow conditions changed?

How? Tell me about that. 
What happens if the winter is not typical?

Transportation

Subsistence

Flooding

What subsistence activities take place in the winter?

Do you participate in any of these?

Can you tell me more about that?

How far do people travel to participate in these activities?

Has that changed?

Have you noticed any changes (in subsistence fish or animals the participant mentions) over the years?

Is there anything else you'd like to tell me about winter?

Let's talk about spring now...

Can you tell me what a typical spring is like?

When does the snow begin to melt?

When does the river ice typically break up?

What is that like?

\section{Do you remember a spring that was not typical?}

What was that like?

When was that?

What are the signs that a spring is not typical?

Were the temperatures warmer? Colder?

Did the snow melt earlier? Later?

Did the river break up earlier? Later? Differently? What was different?

Did you notice changes in the timing of the plants budding? 
What subsistence activities take place in the spring?

Do you participate in any of these?

Can you tell me more about that?

How far do people travel to participate in these activities?

Has that changed?

Have you noticed any changes (in subsistence plants or animals the participant mentions) over the years?

Is there anything else you would like to tell me about the spring?

Now I'd like to ask you the same questions about the summer...

Can you tell me about a typical summer?

When does it start to get warm?

How warm does it get?

When does it start to get dry?

When does it start to get wet?

How much rain do you get in the summer?

Do you remember a summer that wasn't typical?

What was that like?

When was that?

What are the signs that a summer is not typical?

Were the temperatures warmer? Colder?

What subsistence activities take place in the summer?

Do you participate in any of these?

Can you tell me more about that?

How far do people travel to participate in these activities?

Has that changed? 
Have you noticed any changes (in subsistence plants or animals the participant mentions) over the years?

\section{And now let's talk about fall...}

\section{What is a typical fall like?}

When does it start to get cool?

When does the river start to freeze?

When it freezes does it stay frozen or does it thaw and refreeze?

What kind of precipitation do you typically get in the fall?

Rain?

Snow?

What is the snow like in the fall?

What do you call that kind of snow?

\section{Do you remember a fall that wasn't typical?}

What was that like?

When was that?

What are the signs that a fall is not typical?

Were the temperatures warmer? Colder?

Was there less snow? More snow? More or less rain?

Do you notice changes in the timing of the leaves falling?

Different weather patterns?

Different wind patterns?

\section{What subsistence activities take place in the fall?}

Do you participate in any of these?

Can you tell me more about that?

How far do people travel to participate in these activities? 
Has that changed?

Now I'd like to talk more specifically about the river (be specific about what river we are talking about; Yukon/Andreafski, Yukon/Kotlik)... *frame these more specific questions in the context of what has already been discussed... "You said that the river....can you tell me more about that?"

What time of year is the river the highest?

What kind of subsistence activities take place when the river is its highest?

When is it the lowest?

What kind of subsistence activities take place when the river is low?

Does your village flood very often?

What time of year would be typical for a flood?

Have there been floods that weren't typical?

Tell me more about that... what happened?

Have you noticed any changes in the river?

What are these changes?

Changes in the banks?

Erosion?

Sandbars-more, less, different places?

Changes in freeze up or break up?

Changes in ice

Why do you think the river is changing?

Do these changes impact you in any way?

How?

What do you do to overcome these impacts?

Do you have concerns about water quality?

What concerns do you have? 
Why do you have these concerns?

Where does your drinking water come from?

Has water quality changed?

Why do you think water quality has changed?

Does this impact you?

\section{How?}

\section{Can you tell me about open leads on the river?}

More? Less? Bigger? Smaller?

Are there places where the river never freezes?

Why?

New or always been there?

Is there anything else you would like to tell me about the river? Let's move on to permafrost...

Can you tell me about permafrost in St. Mary's/Kotlik/Chevak?

Is there a lot of permafrost?

Where is the permafrost?

Do you use permafrost to store food?

\section{Have there been changes in permafrost?}

What kind of changes?

More, less, just different (different how?)?

Are there specific places that permafrost seems to be thawing?

How do you know the permafrost is changing?

Do changes in permafrost impact you?

How? (buildings, injuries, transportation, food storage)

How do you overcome these impacts? 
Finally I thought we could talk about St. Mary's/Kotlik/Chevak...

How long have you lived in St. Mary's/Pilot Station/Kotlik/Chevak?

Where did you grow up?

How far is that?

Is that near the Yukon River? Near the coast?

Can you tell me about what it was like growing up there? What do you value most in your village? (or What is most meaningful to you in your village?)

Tell me more about that.

Why is that the most meaningful or valuable thing in your village to you?

Is there anything else that you would like to tell me? 